\author{
N. V. Medvedovska1,4, O. G. Shekera2,4, A. M. Nagorna1, Ye. M. Anisimov ${ }^{3}$ \\ ${ }^{1}$ National Academy of Medical Sciences of Ukraine, Kyiv, Ukraine \\ ${ }^{2}$ Shupyk National Healthcare University of Ukraine, Kyiv, Ukraine \\ ${ }^{3}$ Bogomolets National Medical University, Kyiv, Ukraine \\ 4 International Public Organization «International Association «Health of Society», Kyiv, Ukraine
}

\title{
EXPERIENCE OF WORLD ACADEMIC SCIENCE AS A LANDMARK OF MEDICAL SCIENCE DEVELOPMENT IN UKRAINE
}

\begin{abstract}
Background. The previous millennium was marked by the rapid development of scientific and technological progress, the widespread implementation of the results of scientific research. The purpose of our work was a retrospective study of global approaches and historical preconditions for the formation of academic science in different countries, the experience of effective organization of scientific research to develop proposals for its improvement, taking into account the peculiarities of medical academic science in Ukraine. Materials and methods. In the course of the research the methods of semantic analysis of scientific documents, methods of structural-logical analysis, content analysis were used. Results. Historical and modern aspects of academic science formation in different countries of the world were analyzed. Particular attention was paid to the peculiarities of the development of medical academic science with the assessment of the most effective systems of its organization. In Ukraine, national interests require immediate and effective measures aimed at preserving and effectively using existing scientific potential. Specific mechanisms for ensuring proper scientific substantiation of the formation and implementation of state policy in all spheres of public life need to be identified. Conclusions. Improving the system of organization of medical academic science in Ukraine should take into account the results of the emergence and development of academic science, both in Ukraine and in developed countries. The results of the study of international experience testified to the historical expediency and effectiveness of the development of academic medical science. Funding for medical science, which has become a cornerstone of transformation, must be differentiated, this is the mixed model is the most common in the world-basic funding using public funds with the possibility of grant support on a competitive basis. Such a mechanism for the efficient use of public resources will create conditions for stimulating priority and innovative research.
\end{abstract}

Keywords: academic science; experience of origin and formation; organization of effective scientific medical research

\section{Introduction}

The development of mankind is inconceivable without the development of science and advanced technologies, which for many centuries have radically changed the form of human life in all spheres [1, 4, 5].

The French physicist Frederic Joliot-Curie (winner of the Nobel Prize in 1935) wisely predicted: "Science is necessary for every nation. Science opens up grand prospects for those who serve it. A state that does not develop science inevitably becomes a colony. "The decisive role of scientific research is the driving force of progress, which determines the welfare and prospects of social and economic develop- ment of the country, its status in the world and European space. Among the billions of people, only a small number seek to engage in science, most are preoccupied with everyday problems related to the need to support themselves and their families [2].

At all times, the process of forming an elite, especially intellectual, in each country had its own characteristics. Perhaps that is why Alfred Nobel, a prominent entrepreneur, inventor and scientist, understanding all the complexities of scientific research, argued that intellectual research needs material support, providing conditions for their implementation. Realizing this, he gave all his wealth

() «Здоров'я суспільства» / «Здоровье общества» / «Health of Society» («Zdorov'a suspil'stva»), 2021

() Видавці Міжнародна громадська організація «Міжнародна асоціація «Здоров'я суспільства», Заславський 0.Ю. / Издатели Международная общественная организация «Международная ассоциация «Здоровье общества», Заславский А.Ю. / Publishers International Public Organization "International Association "Health of Society", Zaslavsky 0.Yu., 2021

Для кореспонденції: Медведовська Наталія Володимирівна, Національна академія медичних наук України, вул. Герцена, 12, м. Київ, 04050, Україна; e-mail: medvedovsky@ukr.net For correspondence: Nataliia Medvedovska, National Academy of Medical Sciences of Ukraine, Herzen str., 12, Kyiv, 04050, Ukraine; e-mail: medvedovsky@ukr.net 
for financially support the development of science in the world $[3,7]$.

The purpose of the study was a retrospective study of global approaches and historical preconditions for the formation of academic science in different countries, the experience of effective organization of research to develop proposals for its improvement, taking into account the peculiarities of medical academic science in Ukraine.

\section{Materials and methods}

In the process of research the methods of semantic analysis of scientific documents, methods of structural-logical analysis and content analysis were used.

\section{Results}

Science has always been the work of extraordinary and talented people. At all times, scientists in Europe and the world have tried to unite and learn from each other. Royal families and wealthy elites, being highly educated at that time, actively supported innovations and researches. Thus, in 1731, Louis XV founded the Royal Academy of Surgery, and later the Royal Medical Society. Later, in 1820, King Louis XVIII signed a decree establishing the world's first medical academy in Paris. It gradually strengthened in its initiatives with the adoption of the statute of the academy, which is still in force. According to this document, "Bulletin" and "Memoires" are published annually, with the publication of research results of eleven sections of the Academy. At the time of its establishment, the Academy's activities were necessary to respond to government demands on all health issues, mainly epidemics, diseases, examination of new drugs, vaccine distribution, and any research facilities that may contribute to progress, different branches of the healing art. To this day, this mission remains relevant for academic medical science.

Research reports of this institution are taken into account in the work of government agencies. The scope of the Academy's mission covers various areas: drug safety and pharmacovigilance; regulation of the child's school time; prevalence of infectious diseases; promotion of national adoption; medical prevention; stem cells and their therapeutic prospects; modern medical humanism; specialized medical education in France; demographic processes, etc. For examination of subjects of various directions in Academy permanent commissions on a profile are formed.

The Paris National Medical Academy has about four hundred full members and corresponding members. The Academy has always consisted of five people (President, Vice President, Secretary General, Deputy/Assistant Secretary General, Treasurer). According to the charter, the academy receives annual subsidies from the state. The traditions established in 1820-1835 continue to this day, and the members of the Paris National Medical Academy include advising French policymakers on public health, healthcare reforms and international science. For almost two hundred years of existence of the world's first Academy of Medical Sciences, its members were 11 Nobel laureates.

The positive experience of creating an academic association of medical research has led to the creation of medical academies in other European countries and the world. In 1841, by order of King Leopold I, a state institution was established - the Royal Medical Academy of Belgium, which in the early years was subordinated to the Minister of the Interior, Baron JB Natomb. According to the king's decree (1925), the management of the heritage of the medical academy is managed by the royal family to this day. Areas of research of this academy cover the fields of human medicine, animal medicine, pharmacy and some related fields. The Academy is an advisory body for government agencies, federal and regional authorities and a research center for researchers. To publish the results of health research, the Royal Medical Academy of Belgium publishes reports, holds monthly forum sessions for conferences and scientific debates, and supports active publishing and international activities. The Academy is managed by a Board consisting of a Chairman, a Permanent Secretary, two Deputy Chairmen and three assistants. There are six categories of members in the academy: permanent (about 70 people); associate members; honorary members; foreign members, honorary foreign members.

In 1879, the Royal National Medical Academy was founded in Spain, which today is one of eight academic institutions with a national status, whose research activities are regulated by the "National Plan for Science and Development". One of the main tasks of the Academy is to promote the world progress of medical science through the strictest selection of outstanding scientists, researchers and professors. Among the state priorities of scientific activity are: introduction of scientific researches taking into account the general benefit for the society; social protection of citizens; strengthening the competitiveness of the economy; strategies for health, biotechnology, energy and climate change, telecommunications and the information society $[6,9]$. In the field of health care, the following thematic groups are singled out as priorities: the use of molecular and cellular technologies for human health; conducting research in the field of health, environment and occupational health; development of pharmaceutical technologies. The Academy's charter provides for the preparation of a report for the government on medicine and health care, as well as answers to inquiries when special scientific knowledge is required. The academy sends scientific initiatives to the government, which are mandatory for consideration. In 1921, Nicasio Mariscal started a journalistic field of work at the Academy, which not only fills the classical library of Spanish medicine, but also collects and publishes materials of Critical History and Bibliography of Medicine, prepared a Technological Dictionary of Medicine.

The National Academy of Medical Sciences of Ukraine has a positive experience of cooperation with scientists of the Royal National Academy of Medicine in the framework of international cooperation on topical issues of modern medicine, in particular with the Valencia Institute of Oncology (2005).

It is known, including international activities of the Academy of Medical Sciences Portland Place (UK), which was established in 1998 as a non-governmental organization that can have multi-channel funding. According to recently published reports, the state subsidy for the maintenance of 
the academy is $25-30 \%$, the rest of the proceeds come from charitable foundations, contributions from industrialists, trade and investment income. The British Academy of Medical Sciences has 1,094 full members and 40 honorary members. For example, the academy is actively involved in the development of EU regulations on medical devices during the legislative process, monitors the implementation of EU clinical trial regulations and EU data protection regulations, the academy has an authoritative voice in planning and creating training programs. Recently, the regulation and management of research in "UK health with people, their tissues or their data" has been subject to a review initiated by the government, in particular to change the regulatory framework and governance structure around medical research. The Helix Group, which includes patrons who support the ability to meet the current challenges of the biomedical sciences while ensuring the independence of scientific research [9]. To streamline the regulation and management of health research, it is proposed to establish a new agency and a National Research Management Service to facilitate the timely approval of research by NHS trusts.

The National Academy of Medical Sciences of the United States was founded in the twentieth century (1970), initially as an "Institute of Medicine" within the National Academy of Sciences. Since 2015 alone, it has become the National Academy of Medicine, under the auspices of which more than 2,000 members work on a voluntary basis. Research institutes and research centers (each with its own profile, a total of 27) are subordinate to the US Department of Health and Human Services under the common name National Institutes of Health. Their budgets form the cost of the so-called internal research program (about $\$ 26$ billion annually). The National Academy of Medical Sciences is an organizational body that works with the support of the state in the coordination of research activities, standards of scientific disciplines, plays an important organizational role in academic exchange and cooperation between countries. About $60.0 \%$ of the annual budget of the academy consists of contributions from external donors and grants. The National Academy of Medicine provides national and international consultations on health, medicine, health policy and biomedical sciences. The Academy relies on the voluntary cooperation of scientists and other experts, annually their membership is supplemented by newly elected members (not more than 80 people). Committees work to ensure the necessary expertise and avoid bias in decision-making or conflicts of interest. Each report of the committee is widely reviewed and evaluated by external experts who work anonymously, which ensures complete impartiality of decision-making. The number of permanent members of the academy, including foreign ones, exceeds 2,000, the statute stipulates that a quarter of the elected members of the NAM are elected outside the medical specialties (social, behavioral, natural sciences, law, administration, engineering). This approach allows the Academy to remain, according to the New York Times, "the most respected and authoritative health adviser transforming medical thinking worldwide".

In many countries, one national academy covers all disciplines, including the Department of Medical Sciences. An example of this approach is the world's first German Academy of Naturalists "Leopoldina" (Halle), which was founded on a private initiative (1652) by four German doctors and naturalists, as a scientific society for the exchange of ideas, which was later joined by others colleagues. At the end of the 17th century, Kaiser Leopold I established the status of the academy by a special decree as a leading association of German scientists studying natural phenomena. Among Leopoldina's academics there are 166 Nobel Prize winners, 1,300 scientists are members of the academy, they work in the field of natural sciences and medicine. The management of the academy is regulated by the statute, management regulations and the electoral code. The academy is headed by a bureau (president, four vice-presidents, four secretaries), members of the presidium are elected by the Senate, their term of office is 5 years. The main tasks of Leopoldina, as a national academy, include consulting services for German politicians, representation of Germany at the international level. In the field of view of the institution, for example, are issues related to global climate change, demographic processes, energy, social and economic crises, their impact on society.

The M. Planck Society ("umbrella society", which unites about 30 research institutes) demonstrates another model of research organization in Germany. The company and its institutions receive various grants for projects from the state, about $50.0 \%$ of the basic budget is provided by the federal government, the rest at the expense of federal governments. The most "expensive" are the areas of biology, physics, chemistry, social sciences.

In Germany, there is also the Association of German Research Centers named after Helmholtz, whose members are: the German Center for Neurodegenerative Diseases, the German Cancer Research Center, a Center for Molecular Medicine. M. Delbruck and others. The total annual budget of the Association by $70.0 \%$ is institutional funding from the state, up to $30.0 \%$ of funding is competitive (grant) funding, including from EU structures.

The Swiss Academy of Medical Sciences (SAMS) was founded as a research institution with annual state support in 1943. Research is carried out under two programs: Medical Science and Practice, Medicine and Society, which can be funded by private foundations and the state in the form of subsidies. This academy is part of the Swiss Academies of Arts and Sciences, funded by the Swiss National Science Foundation, which is responsible for funding major research projects. The highest governing body is the Senate, the Executive Committee of the Academy oversees its activities, an administrative work is entrusted to the General Secretariat. The purpose of the Swiss Academy of Medical Sciences was: to support research and education of scientific youth; establishing cooperation between scientists and medical practitioners; intensification of interaction with other countries of the world. Today the Supreme Council of the Academy includes academicians, corresponding members, representatives of medical and veterinary faculties of universities, representatives of professional medical associations. The development program of the academy for 2017-2020 includes: support for young scientists; support for advanced research 
in the field of biomedical and clinical research; connection of medical science with practice; ethical issues related to medical developments (organ transplantation, artificial insemination, euthanasia, etc.); the future of medicine, its impact on people and society; expert and advisory activities for public authorities, research in the field of higher education and prospects for the development of science.

Relatively "young" is the Australian Academy of Health and Medical Sciences (2014), which, as a self-governing and independent organization, has 132 members. Associate membership for promising young scientists is possible within the academy. Funding for the activities of the academy is due to orders for analysis and research in the field of medicine from the state, private organizations. At the same time, the academy has a medical department with a budget for an annual order for research. The budget may include both public funds and extra budgetary sources from individuals and organizations, charitable contributions.

The Croatian Academy of Medical Sciences, founded in 1961, aims to support scientific and technical research in the field of medicine, the dissemination of cultural and scientific progress for the benefit of mankind.

The Guatemalan Academy of Medical, Physical and Natural Sciences (Academia de Ciencias Medicas, Físicas y Naturales de Guatemala), founded in 1945, regularly presents scientific expertise and disseminates information on the state of ecosystems, the dissemination of cultural and scientific progress, and their implementation. the good of mankind. The Academy belongs to the group of Affiliated (affiliation - "connection, connection" from the Latin filialis - "filial") scientific organizations and academies of sciences in developing countries, regularly fills in and receives technical and consolidated reports for review and dissemination among experts, the latter of the international projects to which the academy actively participated was the "Millennium Ecosystem Assessment".

In China, the Chinese Academy of Sciences has an academic division of life sciences and medical sciences, established six years after the founding of the academy itself. Medical science is funded by the National Science Foundation of China, which has had a medical department since 2010. Recently, health care costs have increased significantly, especially in research in cell engineering, biotechnology, stem cell applications, and nanotechnology in medicine [8].

While most academies are state or partially state-funded, there are examples of institutions that operate on a private basis. First of all, it is worth mentioning the Pasteur Institute in Paris, which has repeatedly made discoveries of the century aimed at studying infectious diseases (the last of which was discovered in 1983 by the human immunodeficiency virus). The Institute is a non-profit private foundation that guarantees independence and financial support to its scientists (under its leadership it unites more than 100 institutions from 70 countries). The institute has the right to charge for licensing procedures, consulting services, contracts with private institutions, a significant amount of research is funded by subsidies from the French government.

In the Soviet Union, the positive world experience of the development of academic science was effectively used.
Academies, institutes, laboratories were actively created, funds were invested in the development of scientific bases, young people were actively interested in scientific research, this formed the prestige and value of personal development in the individual plan. Soviet science was characterized by strategic planning focused on the desired result, both in industry and in medicine. On the other hand, the development of scientific research took place in a certain isolation from world science in the spirit of competition between countries for innovations that became breakthroughs in various sectors of the economy.

The Russian Academy of Medical Sciences in 2013 was reformed by joining the Russian Academy of Sciences. At the time of the reorganization, the RAMS had more than 200 academics and 217 corresponding members. In the countries of the former Soviet Union, after its collapse, national academies were also established (in Belarus, Latvia, Moldova, Lithuania, Kazakhstan, Uzbekistan, Mongolia).

The Ukrainian Academy of Sciences was established for the first time in 1918 during the time of Hetman Pavlo Skoropadsky, later it became the All-Ukrainian Academy of Sciences, the Academy of Sciences of the Ukrainian SSR, and now the National Academy of Sciences of Ukraine. Later, in 1944, the Academy of Medical Sciences was established under the Ministry of Health of the USSR. Immediately after the collapse of the Soviet Union in 1991, the Department of Medical Problems functioned at the Academy of Sciences of Ukraine, which was transformed into the Academy of Medical Sciences of Ukraine. According to the Law "Fundamentals of Health Care Legislation", the NAMS is a self-governing organization, independent in conducting research and development of research areas. Since 2010, the Academy of Medical Sciences has received the status of the National and unites in its activities 36 state scientific institutions. It is this experience of combining scientific research and therapeutic, clinical work on thematic patients, proved to be effective. With the adoption of the Law "On Higher Education" in Ukraine began the transition to European standards in science, the law prescribes new rights and responsibilities of the National Academy of Sciences of Ukraine, as the chief administrator of budget funds and self-governing scientific organization, whose activities, in part, not violates self-government, coordinated by the Cabinet of Ministers of Ukraine. In Ukraine, as in most countries of the world, the development of the scientific sphere is supported by the state. There is no doubt that domestic science has significant achievements, the number of world-renowned publications with the results of scientific research with the participation of domestic medical scientists is growing.

\section{Discussion}

The debate about continues of science reform, the current state of which is explained by the temporary difficulties associated with insufficient funding. Discussions are taking place on the feasibility of implementing the transition from basic to competitive (grant) funding, the need for changes in the management system of science, its approach to production (including the use of private sector sponsorship in research to order) and commercialization with optimization 
of business management scientific institutions. The ongoing discussions are united by the idea of the expediency of preserving and supporting positive initiatives that have proved their effectiveness in implementation (medical, social, economic), to preserve the human potential of researchers, scientists, adding young scientists who will be interested in working on updated scientific bases with attractive remuneration. Under such conditions, it will be possible to increase the prestige of Ukrainian medical science, stop the "outflow" of gifted youth abroad.

Modern Ukrainian realities of the prospects for the development of medical science encourage changes, the vectors of which are on the verge of cardinal contradictions. On the one hand, a clear state understanding that the development of science in Ukraine, as a state of the European region, is an indicator of the level of development of national institutions, a guarantee of national security prospects, progressive development and strengthening of the state by modern scientific and technical level, the medical sphere, becomes a guarantee of hopes for positive changes to take place in the near future. Numerous parliamentary hearings on "About the state and legislative support for the development of science and scientific and technical sphere of the state", which were actively involved by scientists, show that this issue has not fallen out of sight of the executive and legislature. On the way to Ukraine's European integration there is a positive experience of active development of the economies of the world's leading countries, the key role in which is played by science and technology, increasing the science intensity of GDP, increasing the share of funds, financial, resource and human resources. GDP of countries with rapid economic development reaches $90.0 \%$. On the other hand, there are realities in which, during the 30 years of independence in Ukraine, there has been a critical decrease in the qualitative and quantitative indicators of scientific potential. The steady downward trend in the share of GDP in the expenditures of domestic science has not only led to a significant reduction in the number of researchers, the prestige of the scientific sphere is being lost, especially for young people. The scientific bases on which the share of obsolete equipment grows over the years need to be modernized. The former practice, when the results of scientific research became the basis for strategic directions of the industry development, state reforms taking into account the peculiarities of Ukraine as a country of the European region and the studied best world experience, is not experiencing the best.

The results of scientific research in medicine, which correspond to the stated priority areas, especially its preventive vector, and relate to the influence of the state on socio-economic development, the preservation of human resources remain realized only in a small part.

Every year, the critical gap between generations of scientists grows. The older generation may not have time to pass on their skills and abilities to the next generation to form a scientific vision and thinking. Young people who come to science are detained for a short period of time, for example, due to dissertation research, and after realizing their financial inability to successfully support their families, prefer to work abroad, in private institutions, and so on. Instead, disputes continue over the renewal of the principles of budget funding of state academies, including NAMS of Ukraine, optimization of the structure of the network of institutions and establishments in order to unite or eliminate inefficient institutions, change their subordination, etc. The question arises whether domestic medical science will survive in such conditions?

It is high time to break the negative trends. The vector of state policy should be aimed at forming a qualitatively new scientific and technical potential and providing conditions for its most effective use. The efforts of state scientific institutions should be focused on the most priority and promising areas for implementation in our conditions, which correspond to the world trends in the development of medical science. It is necessary to modernize the management of the institutions of the National Academy of Medical Sciences of Ukraine with the organization of interdepartmental cooperation, cooperation with representatives of other theoretical disciplines. The NAMS of Ukraine is gradually introducing such integration, in the previous year in 24 of 36 scientific institutions joint scientific developments were carried out, in particular with institutions of the NAS of Ukraine (19), the Ministry of Health of Ukraine (18), the Ministry of Defense of Ukraine (4), the Ministry of Internal Affairs (1), Higher Educational Institutions (19), Higher Medical Educational Institutions (23). The number of such works is growing, although the mechanism of mutual settlements between institutions of different departments is difficult, most of the co-executors carry out these researches free of charge, having joint publications.

In the current economic conditions in the country as a whole, and medical science in particular, it is advisable to use world achievements with access to their own concepts, theories, methodologies and technologies that could ensure the avant-garde position of domestic medical science.

The greatest attention should be paid to basic research, innovations with their widespread implementation in the field of health care, increasing the competitiveness of research results in the global market of scientific products and medical services.

In modern conditions it is necessary not to spray, but to focus on current "breakthrough" areas of medical science, the development of the final product which is possible with the participation of several diverse institutions requires concentration of equipment and methodological capabilities of different scientific bases. To achieve the desired effect on this path, it is necessary to clarify and take into account: the state of the domestic scientific sphere with bringing it in line with modern world-class requirements; connection of science with practice (health care facilities, production, business projects, private structures) for effective implementation of innovations; the level of expenditures that the state directs to the development of national science.

The Strategy of reforming and development of medical science developed in NAMS of Ukraine is called to intensify researches and developments directed on increase of science intensity, competitiveness, formation of investment attractiveness of domestic medical developments, with growth of 
specific weight in them of scientifically proved innovative methods and approaches.

In Ukraine, national interests require immediate and effective measures aimed at preserving and effectively using existing scientific potential. Specific mechanisms for ensuring proper scientific substantiation of the formation and implementation of state policy in all spheres of public life need to be identified. The Law of Ukraine "On Scientific and Scientific-Technical Activity" opens the possibility of competitive funding of scientific research, as almost now their basic budget funding is carried out, for this purpose the National Research Fund was established, whose work is full of hopes for the return of prestige in the state.

\section{Conclusions}

The results of the study of international experience testified to the historical expediency and effectiveness of the development of academic medical science. Our country has significant developments that need to be used in modernizing in response to today's challenges. Funding for medical science, which has become a cornerstone of transformation, must be differentiated, this is the mixed model is the most common in the world - basic funding using public funds with the possibility of grant support on a competitive basis, as public funds allocated to priority programs for the development of science in the country, as well as funds of industries, private investors or institutions to carry out research work. Such a mechanism for the efficient use of public resources will create conditions for stimulating priority and innovative research, which is essential at this stage.

Conflicts of interests. Authors declare the absence of any conflicts of interests and their own financial interest that might be construed to influence the results or interpretation of their manuscript.

\section{References}

1. Юваль Ной Харари. «Sapiens. Краткая история человечества». - Big Ideas, 2016. - 512 c.

2. Храмов Ю. А. Жолио-Кюри Фредерик (Joliot-Curie Frederic) // Физики: Биографический справочник / Под ред. А. И. Ахиезера. - Изд. 2-е, испр. и доп. - М.: Наука, 1983. - C. 112. - 400 c.

3. Овчинников В. В. Технологии глобальной конкуренции. - М.: ИНЭС-МАИБ, 2012.

4. Яковеи Ю. В. Глобальные экономические трансформации ХХІ века. - М.: Экономика, 2011. - 377 c.

5. Bostrom N. Super Intelligence: Paths, Dangers, Strategies. - Oxford: Oxford UniversityPress, 2014.

6. Beinke JH, Fitte C, Teuteberg F. Towards a Stakeholder-Oriented Blockchain-Based Architecture for Electronic Health Records: Design Science Research Study. // J Med Internet Res. - 2019;21(10):135-85. DOI: 10.2196/13585.

7. Chen HS, Jarrell JT, Carpenter KA, Cohen DS, Huang X. Blockchain in Healthcare: A Patient-Centered Model. // Biomed J Sci Tech Res. - 2019;20(3):15017-22. PMID: 31565696.

8. Bondar-Pidhurska OV, Hliebova AO, Khomenko II. Nanotechnology as a basis for implementing the paradigm of national economy development. // Economics and Region. -2017;3(64):22-30. - Available from: http://nbuv.gov.ua/ UJRN/econrig_2017_3_6.

9. Kahl M, Gertig M, Hoyer P, Friedrich O, Gilbert DF. Ultra-Low-Cost 3D Bioprinting: Modifiation and Application of an Offthe-Shelf Desktop 3D-Printer for Biofabrication.// Front Bioeng Biotechnol. - 2019;7:184. DOI: 10.3389/ fbioe.2019.00184.

Received 12.02.2021

Revised 24.02.2021

Accepted 28.02.2021

Медведовська Н. В. ${ }^{1,4}$, Шекера О. Г. ${ }^{2,4}$, Нагорна А. М. ${ }^{1}$, Анісімов $\in$. M. $^{3}$

${ }^{1}$ Національна академія медичних наук України, м. Київ, Україна

${ }^{2}$ Національний університет охорони зАоров'я України імені П. А. Шупика, м. Київ, Україна

${ }^{3}$ Національний медичний університет імені О. О. Богомольця, м. Київ, Україна

4Міжнародна громадська організація «Міжнародна асоціація «ЗАоров'я суспільства», м. Київ, Україна

\section{АОСВIА СВITОВОÏ АКААЕМІЧНОÏ НАУКИ ЯК ОРІЄНТИР РОЗВИТКУ МЕАИЧНОÏ НАУКИ В УКРАЇНі}

Резюме. Актуальність. Минуле тисячоліття ознаменувалось стрімким розвитком науково-технічного прогресу, широким впровадженням результатів наукових досліджень у життя. $\mathbf{M e}$ тою нашої роботи стало ретроспективне дослідження світових підходів та історичних передумов формування академічної науки у різних країнах світу, досвіду ефективної організації проведення наукових досліджень для розробки пропозицій $з$ iii удосконалення, з урахуванням особливостей формування медичної академічної науки в Україні. Mатеріали та методи. В процесі дослідження були використані методи семантичного аналізу наукових документів, методи структурно-логічного аналізу, контент-аналізу. Результати. Проаналізовані історичні та сучасні аспекти формування академічної науки у різних країнах світу. Особливу увагу приділено особливостям розвитку медичної академічної науки з оцінкою найефективніших систем її організації. В Україні національні інтереси вимагають негайних та ефективних заходів, направлених на збереження та ефективне використання наявного наукового потенціалу.
Необхідно визначити конкретні механізми забезпечення належного наукового формування та реалізації державної політики у всіх сферах суспільного життя. Висновки. Удосконалення системи організації медичної академічної науки в Україні повинно відбуватися з урахуванням результатів виникнення та розвитку академічної науки як в Україні, так і в розвинених країнах світу. Вивчення зарубіжного досвіду свідчить про історичну доцільність розвитку академічної медичної науки, а у нашій країні є істотні напрацювання, які необхідно використовувати для іiі модернізації. Фінансування медичної науки повинно бути диференційованим, тобто базове фінансування за рахунок державних коштів з можливістю грантової підтримки на конкурсній основі. Такий механізм ефективного використання державних ресурсів створить умови для стимулювання пріоритетних та інноваційних досліджень.

Ключові слова: академічна наука; досвід виникнення і становлення; організація ефективних наукових медичних досліджень 
Медведовская Н. В. ${ }^{14}$, , Шекера О. Г.,.4, Нагорная А. М. ${ }^{1}$, Анисимов Е. H. ${ }^{3}$

${ }^{1}$ Национальная акалемия медицинских наук Украины, г. Киев, Украина

${ }^{2}$ Национальный университет зАравоохранения Украины имени П. А. Шупика, г. Киев, Украина

${ }^{3}$ Национальный меАицинский университет имени А. А. Богомольца, г. Киев, Украина

${ }^{4}$ Межаународная общественная организация "МежАународная ассоциация «ЗАоровье общества», г. Киев, Украина

\section{ОПЫТ МИРОВОЙ АКААЕМИЧЕСКОЙ НАУКИ КАК ОРИЕНТИР РАЗВИТИЯ МЕАИЦИНСКОЙ НАУКИ} В УКРАИНЕ

Резюме. Актуальность. Предыдущее тысячелетие ознаменовалось стремительным развитием научно-технического прогресса, широким внедрением результатов научных изысканий в жизнь. Целью нашей работы стало ретроспективное исследование мировых подходов и исторических предпосылок формирования академической науки в разных странах мира, опыта эффективной организации проведения научных исследований для наработки предложений по ее усовершенствованию, с учетом особенностей формирования медицинской академической науки в Украине. Материалы и методы. В процессе исследования были использованы методы семантического анализа научных документов, методы структурно-логического анализа, контент-анализа. Результаты. Проанализированы исторические и современные аспекты формирования академической науки в разных странах мира. Особенное внимание уделено особенностям развития медицинской академической науки с оценкой самых эффективных систем ее организации. В Украине национальные интересы требуют незамедлительных и эффективных мер, направленных на сохранение и эффективное использование имеющегося научного потенциала.
Необходимо определить конкретные механизмы обеспечения надлежащего научного формирования и реализации государственной политики во всех сферах общественной жизни. Bbводы. Усовершенствование системы организации медицинской академической науки в Украине должно происходить с учетом результатов возникновения и развития академической науки, как в Украине, так и в развитых странах мира. Изучение зарубежного опыта свидетельствует об исторической целесообразности развития академической медицинской науки, а в нашей стране есть существенные наработки, которые необходимо использовать в её модернизации. Финансирование медицинской науки должно быть дифференцированным, то есть базовое финансирование за счёт государственных средств с возможностью грантовой поддержки на конкурсной основе. Такой механизм эффективного использования государственных ресурсов создаст условия для стимулирования приоритетных и инновационных исследований.

Ключевые слова: академическая наука; опыт возникновения и становления; организация эффективных научных медицинских исследований 